\title{
Struktur Komunitas Siput Laut (Kelas : Gastropoda) di Pesisir Dusun Karang Utara, Pulau Lemukutan
}

\author{
Weni Magdalena $^{1 *}$, Arie Antasari Kushadiwijayanto ${ }^{1}$, Yudha Perdana Putra ${ }^{1}$ \\ 1 Program studi Ilmu Kelautan, FMIPA, Universitas Tanjunpura, Pontianak- \\ Indonesia \\ 2 Jurusan Kelautan dan Perikanan, Politeknik Negeri Pontianak, \\ Pontianak-Indonesia \\ *Correspondence email: Weni Magdalena \\ $\triangle$ wenimagdalena@gmail.com
}

\author{
Received : 11 January 2019 - Accepted: 25 March 2019 \\ Published: 30 June 2019 @ Author(s) 2019. This article is open access
}

\begin{abstract}
Dusun Karang Utara di Pulau Lemukutan telah berkembang dalam sektor pariwisata namun potensi lautnya belum dikelola secara maksimal akan tetapi Dusun Karang Utara memiliki salah satu sumber daya yang melimpah yaitu siput laut. Penelitian ini bertujuan untuk mengetahui struktur komunitas siput laut. Penelitian ini menggunakan teknik purposive sampling untuk penentuan stasiun pengamatan dan metode stratified random sampling untuk penentuan plot sampel. Plot sampel dibentangkan di sepanjang zona pasang surut (intertidal zone). Siput laut yang ditemukan di lokasi penelitian berjumlah 26 spesies yang terdiri dari 14 famili. Spesies yang paling banyak ditemukan yaitu Clypeomorus moniliferus, Cronia margariticola, Rhinoclavis articula dan Rhinoclavis bituberculata. Nilai indeks struktur komunitas siput laut yang didapat antara lain : indeks keanekaragaman ( $\left.\mathrm{H}^{\prime}\right)$ dengan nilai antara $0,66-2,02$, Nilai indeks kemerataan (E) antara 0,24-0,83, nilai indeks dominansi (C) antara $0,16-0,70$. Stasiun II dengan rona lingkungan yang memiliki substrat lumpur berpasir dan terdapat mangrove jenis avicennia merupakan stasiun dengan keanekaragaman siput laut tertinggi di Dusun Karang Utara Pulau Lemukutan.
\end{abstract}

Keywords: Siput laut, Struktur Komunitas, Chypeomorus, Lemukutan, Stratified random sampling

\section{Pendahuluan}

Dusun Karang Utara merupakan salah satu wilayah di Pulau Lemukutan yang cukup berkembang dalam sektor pariwisata, terutama wisata bawah air. Selain dari sektor pariwisata, sebagian besar masyarakat menggantungkan hidupnya pada hasil laut. Salah satu cara yang dapat dilakukan untuk memanfaatkan kekayaan alam sekitar adalah mengelola potensi sumber biota laut yang ada. Siput laut (kelas: Gastropoda) merupakan salah satu hewan yang sering dijumpai di zona intertidal dan jumlahnya cukup banyak namun belum banyak dimanfaatkan masyarakat. Oleh karena itu perlu dilakukan penelitian struktur komunitas siput laut untuk mengetahui beragam jenis siput laut yang daging dan cangkangnya berpotensi dapat dimanfaatkan sebagai salah satu sumber makanan protein tinggi dan kerajinan tangan maupun bahan bangunan bagi masyarakat. 


\section{Metode}

Pengambilan data dilaksanakan pada 1-3 Juli 2018 pada zona intertidal di pantai Dusun Karang Utara, Pulau Lemukutan (Gambar 1). Wilayah pengambilan sampel meliputi 4 stasiun dengan rona lingkungan yang berbeda (Tabel 1). Stasiun ditentukan berdasarkan metode purposive sampling. Selain itu penentuan plot ditentukan dengan metode stratified random sampling (Gambar 2). Metode purposive sampling dan stratified random sampling mengacu pada Kusmana et al., (2015). Parameter fisika-kimia lingkungan yang diambil adalah suhu, zona pasang surut, salinitas dan $\mathrm{pH}$ yang diambil secara langsung (in situ).

Pengambilan sampel siput laut dilakukan pada saat surut. Sampling dilakukan dengan metode kuadrat (petak sampel) ukuran 5 x 5 $\mathrm{m}$. Setiap stasiun terdapat tiga kuadrat $(5 \times 5$ m) yang diletakkan dengan metode acak berlapis. Siput laut yang dijumpai dalam setiap kuadrat diambil dengan tangan. Spesies yang didapat di masukkan dalam plastik bening dan diberi tanda, kemudian di tambahkan alkohol $70 \%$ atau formalin. Identifikasi dilakukan berdasarkan buku kunci identifikasi Kusnadi et al., (2008).

Data yang diperoleh kemudian diolah dengan menghitung indeks keanekaragaman ( $\left.\mathrm{H}^{\prime}\right)$, indeks keseragaman (E), indeks dominansi (D), kelimpahan (K), frekuensi (F), indeks nilai penting (INP) dan parameter fisika-kimia lingkungan.

\section{Hasil dan Pembahasan}

3.1 Parameter Fisikia-Kimia Lingkungan Beberapa parameter fisika-kimia lingkungan yang diukur pada saat penelitian adalah suhu air, salinitas, $\mathrm{pH}$, dan zona pasang surut (Tabel 2). Rata-rata nilai suhu seluruh stasiun yang diperoleh yaitu $29,74^{\circ} \mathrm{C}$. Suhu terendah terdapat pada stasiun III yaitu $29^{\circ} \mathrm{C}$. Rendahnya suhu pada stasiun III diperkirakan karena mendapat naungan pepohonan. Semakin terbukanya suatu perairan dari naungan, maka akan semakin cepat proses transfer panas sinar matahari dibandingkan dengan daerah yang mendapat naungan (Sinaga dan Riwayati, 1999). Sedangkan suhu tertinggi terdapat pada stasiun II yaitu $30,66^{\circ} \mathrm{C}$. Tingginya suhu permukaan air pada stasiun II dapat disebabkan oleh keterbukaan perairan pada lokasi tersebut. Mengacu pada Wijayanti (2007) dikatakan bahwa suhu dapat membatasi sebaran hewan makrobenthos secara geografik dan suhu yang baik untuk pertumbuhan hewan makrobenthos berkisar antara $25-31^{\circ} \mathrm{C}$. Berdasarkan pernyataan tersebut, kondisi suhu pada lokasi penelitian di perairan Lemukutan masih tergolong layak untuk kehidupan siput laut.

Rata-rata nilai salinitas seluruh stasiun yang didapat yaitu $30,08 \%$. Nilai Salinitas ini tidak begitu jauh berbeda dengan penelitian sebelumnya, yang masih dalam kawasan perairan yang sama dalam

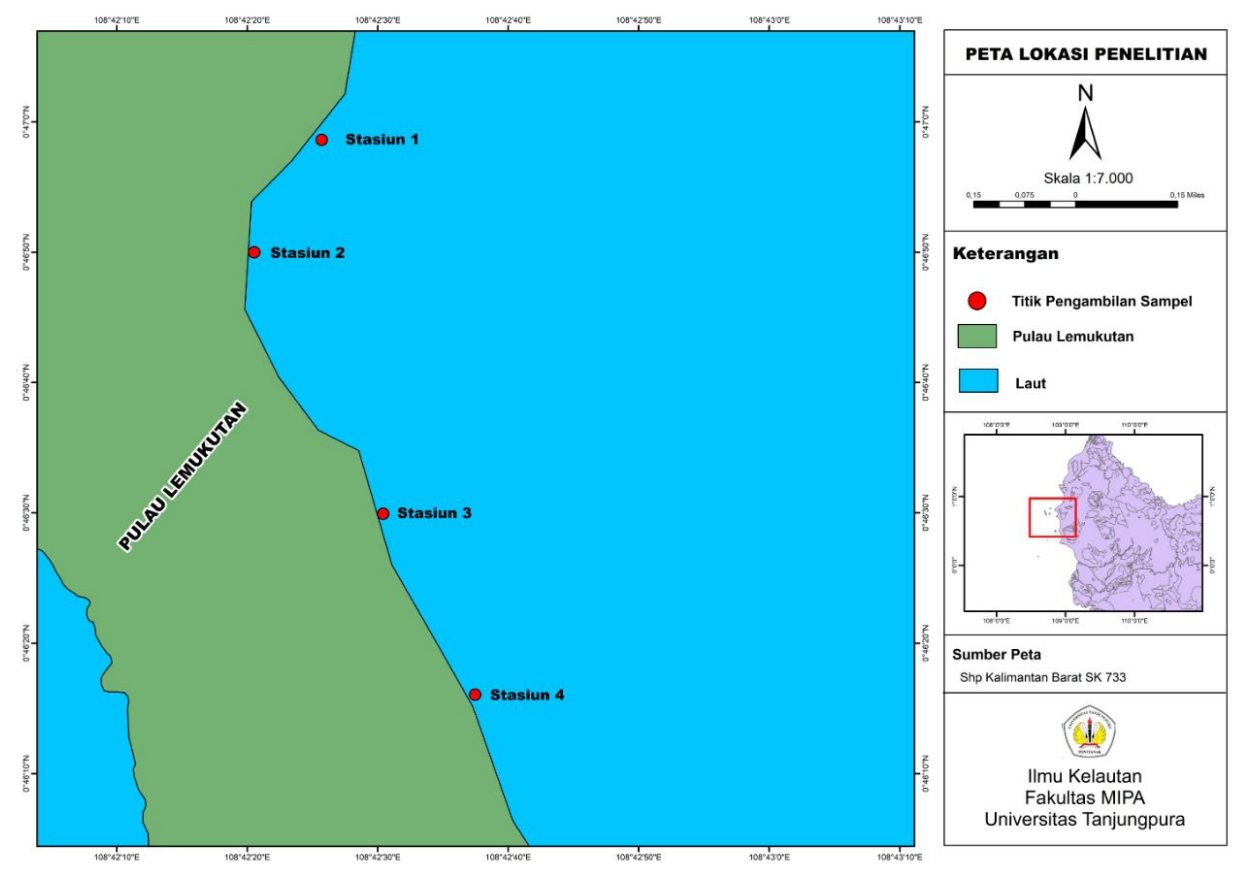

Gambar 1. Peta lokasi stasiun penelitian di Dusun Karang Utara, Pulau Lemukutan 
Tabel 1. Kondisi umum empat stasiun pengambilan sampel di Dusun Karang Utara, Pulau Lemukutan.

\begin{tabular}{|c|c|c|}
\hline Stasiun & Titik Koordinat & Rona Lingkungan \\
\hline 1 & $\begin{array}{l}00^{\circ} 46^{\prime} 58.622^{\prime} \text { LU } \\
108^{\circ} 42^{\prime} 25.70^{\prime} \text { ' BT }\end{array}$ & $\begin{array}{l}\text { Memiliki substrat pasir berbatu, lokasi berada di dekat } \\
\text { dermaga Teluk Cina }\end{array}$ \\
\hline 2 & $\begin{array}{l}00^{\circ} 46^{\prime} 49.99 ” \mathrm{LU} \\
108^{\circ} 42 ’ 20.53 ” \mathrm{BT}\end{array}$ & $\begin{array}{l}\text { Memiliki substrat lumpur berpasir, lokasi berada dekat } \\
\text { dengan area pemukiman warga, yang mana di wilayah } \\
\text { tersebut terdapat beberapa pohon mangrove jenis } \\
\text { Avicennia }\end{array}$ \\
\hline 3 & $\begin{array}{l}00^{\circ} 46^{\prime} 29.94 ” \mathrm{LU} \\
108^{\circ} 42^{\prime} 30.41^{\prime \prime} \mathrm{BT}\end{array}$ & $\begin{array}{l}\text { Memiliki substrat berbatu kerikil, lokasi berada di dekat } \\
\text { area taman Kima }\end{array}$ \\
\hline 4 & $\begin{array}{l}00^{\circ} 46^{\prime} 15.81 ” \mathrm{LU} \\
108^{\circ} 42^{\prime} 36.65^{\prime \prime} \mathrm{BT}\end{array}$ & $\begin{array}{l}\text { Memiliki substrat berbatu, lokasi berada di area batas } \\
\text { wilayah dusun Karang Utara }\end{array}$ \\
\hline
\end{tabular}

penelitian Sudiono (2008), di Kawasan Konservasi Laut Daerah (KKLD) Pulau Randayan dan sekitarnya, yaitu berkisar antara 21-30\%. Hasil nilai pengamatan salinitas yang dilakukan di Pesisir Dusun Karang Utara, menunjukkan bahwa kisaran salinitas yang didapat dari penelitian ini masih dalam kisaran nilai toleransi siput laut, salinitas berpengaruh bagi pertumbuhan kehidupan siput laut sesuai dengan pernyataan Wijayanti (2007), dimana kisaran salinitas optimal bagi siput laut berkisar antara $26-32 \%$.

Rata-rata nilai $\mathrm{pH}$ seluruh stasiun yang diperoleh yaitu 7,80. $\mathrm{pH}$ tertinggi berada pada stasiun I dengan nilai 7,64 dan $\mathrm{pH}$ terendah berada pada stasiun IV dengan nilai 7,88. Tingginya nilai $\mathrm{pH}$ berkaitan erat dengan kondisi perairan yang relatif terbuka. Menurut Schaduw (2018), perairan terbuka cenderung memiliki nilai $\mathrm{pH}$ yang lebih tinggi dibandingkan dengan perairan tertutup, pulau kecil memiliki nilai $\mathrm{pH}$ yang cenderung basa dan pulau besar dengan banyak aliran sungai cenderung menurunkan nilai pH menjadi asam (Schaduw, 2018). Perairan dengan $\mathrm{pH}$ terlalu tinggi atau rendah akan mempengaruhi ketahanan hidup organisme yang hidup didalamnya. Menurut Wijayanti (2007), bahwa pH yang mendukung kehidupan Mollusca berkisar antara 5,7-8,4. Nilai $\mathrm{pH}$ yang di dapat di pesisir Dusun karang Utara ini tergolong ke dalam kondisi yang masih dapat ditoleransi oleh siput laut karena masih dalam nilai kisaran dan baku mutu yang di tetapkan.

\subsection{Keanekagaraman Jenis Siput Laut} Berdasarkan hasil penelitian, didapatkan 26 spesies siput laut di Pesisir Dusun Karang Utara, Pulau Lemukutan. Individu yang ditemukan terdiri dari 14 famili. Jenis siput

\section{Keterangan :}

\section{$\begin{array}{llll}\text { St. } 4 & \text { St. } 3 & \text { St. } 2 & \text { St. } 1\end{array}$}

St $=$ Stasiun

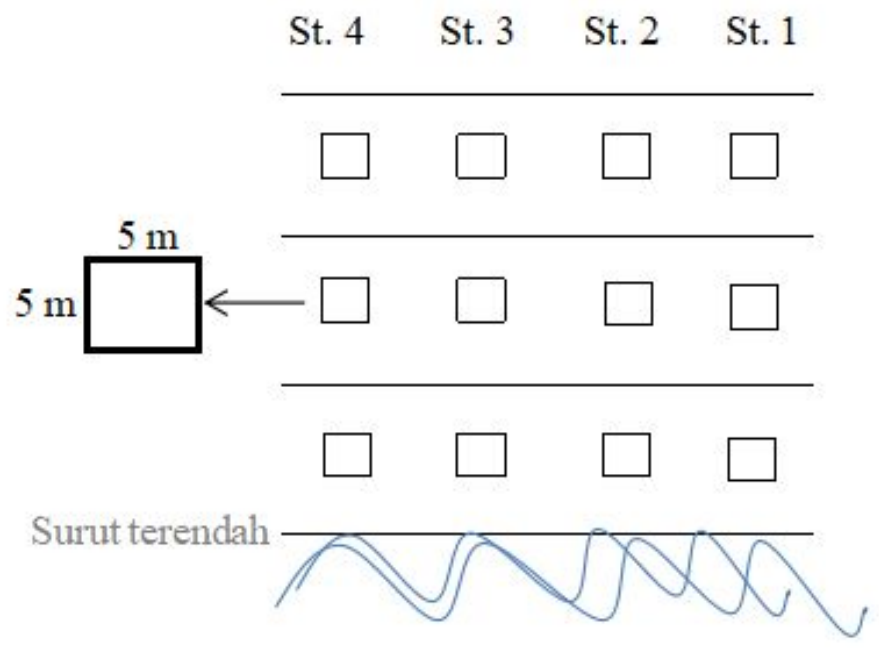

Gambar 2. Peta Contoh desain pengambilan sampel 
Tabel 2. Parameter fisika-kimia lingkungan di Pesisir Dusun Karang Utara, Teluk Cina, Pulau Lemukutan, Kabupaten Bengkayang

\begin{tabular}{cccccc}
\hline \multirow{2}{*}{ Parameter } & \multicolumn{4}{c}{ Stasiun } & \multirow{2}{*}{ Rata-Rata } \\
\cline { 2 - 5 } & I & II & III & IV & \\
\hline Jarak zona pasang surut (m) & 49 & 158 & 28 & 22 & 64,25 \\
Suhu $\left({ }^{\circ} \mathrm{C}\right)$ & 29,33 & 30,66 & 29 & 30 & 29,74 \\
Salinitas (\%o) & 30,33 & 29,66 & 30 & 30,33 & 30,08 \\
pH & 7,88 & 7,86 & 7,83 & 7,64 & 7,80 \\
\hline
\end{tabular}

laut didominasi oleh anggota Famili Cherithiidae dengan jumlah 9 spesies. Total jumlah individu siput laut dari seluruh stasiun sebanyak 8.568 individu. Spesies yang paling mendominasi yaitu spesies Clypeomorus moniliferus yang ditemukan di 2 stasiun yaitu di stasiun II dan stasiun III. Perbedaan jumlah penyebaran individu ini dipengaruhi oleh berbagai faktor salah satunya yaitu kondisi atau rona lingkungan yang relatif berbeda pada masing-masing stasiun. Selain Clypeomorus moniliferus, spesies lain dengan jumlah individu terbanyak yang ditemukan adalah Cronia margariticola, Rhinoclavis articula dan Rhinoclavis bituberculata. Keanekaragaman dan kelimpahan siput laut yang ditemukan di Pesisir Dusun Karang Utara, Pulau Lemukutan dapat dilihat pada Tabel 3.

Spesies Clypeomorus moniliferus, terdistribusi pada daerah beriklim tropis, dan sebagian besar berada di wilayah Indo-Pasifik. Clypeomorus moniliferus memiliki bentuk cangkang oval-fusiformis yang bertekstur tebal dan padat (Gambar 3). Pada permukaan cangkang terdapat varix

Tabel 3. Spesies Siput Laut di Pesisir Dusun Karang Utara, Teluk Cina, Pulau Lemukutan

\begin{tabular}{|c|c|c|c|c|c|c|c|c|c|}
\hline \multirow{2}{*}{ No } & \multirow{2}{*}{ Spesies } & \multicolumn{2}{|c|}{ Stasiun I } & \multicolumn{2}{|c|}{ Stasiun II } & \multicolumn{2}{|c|}{ Stasiun III } & \multicolumn{2}{|c|}{ Stasiun IV } \\
\hline & & $\mathrm{K}$ & INP & $\mathrm{K}$ & INP & $\mathrm{K}$ & INP & $\mathrm{K}$ & INP \\
\hline 1 & Bittium glaerosum & - & - & 6,56 & 13,07 & - & - & - & - \\
\hline 2 & Cerithiopsis stejnegeri & 0,04 & 8,59 & 0,32 & 3,37 & - & - & - & - \\
\hline 3 & Cerithium columna & 0,04 & 8,59 & - & - & 0,16 & 4,72 & - & - \\
\hline 4 & Cerithium dialeucum & - & - & 2,04 & 5,21 & - & - & 0,16 & 11,52 \\
\hline 5 & Cerithium punctatum & 0,12 & 14,65 & 14,41 & 24,50 & - & - & 0,08 & 13,26 \\
\hline 6 & Clypeomorus brevus & 0,04 & 8,59 & - & - & - & - & - & - \\
\hline \multirow[t]{2}{*}{7} & Clypeomorus & & & & & & & & \\
\hline & moniliferus & - & - & 2,00 & 5,17 & 21,75 & 88,04 & - & - \\
\hline 8 & Rhinoclavis articula & - & - & 16,47 & 26,70 & 0,08 & 4,44 & 0,08 & 8,26 \\
\hline \multirow[t]{2}{*}{9} & Rhinoclavis & & & & & & & & \\
\hline & bituberculata & 0,04 & 8,59 & 15,95 & 26,14 & 0,10 & 8,68 & - & - \\
\hline 10 & Collonisca verruca & - & - & - & - & 0,30 & 9,38 & 0,52 & 26,20 \\
\hline 11 & Columbella mercatoria & 0,04 & 8,59 & - & - & - & - & - & - \\
\hline 12 & Cronia margariticola & 0,46 & 51,52 & 16,25 & 26,47 & 0,24 & 5,00 & 0,57 & 38,37 \\
\hline 13 & Morula margariticola & - & - & 2,28 & 5,47 & 0,04 & 12,64 & 0,04 & 6,63 \\
\hline 14 & Cymatium pileare & 0,04 & 8,59 & - & - & - & - & - & - \\
\hline 15 & Cyprea clylindrica & - & - & 0,12 & 3,16 & 0,08 & 4,44 & - & - \\
\hline 16 & Engina alveolata & - & - & 1,68 & 7,86 & 0,04 & 4,31 & 0,16 & 16,52 \\
\hline 17 & Littorina intermedia & - & - & - & - & 4,78 & 24,94 & - & - \\
\hline 18 & Mitra paupercula & 0,04 & 8,59 & 3,36 & 12,68 & 0,32 & 5,28 & 0,35 & 11,63 \\
\hline 19 & Mitra sp.1 & 0,04 & 8,59 & - & - & - & - & 0,04 & 29,12 \\
\hline 20 & Nerita exuvia & - & - & - & - & 0,08 & 4,44 & - & - \\
\hline 21 & Nerita undata & 0,04 & 8,59 & 1,42 & 7,58 & 0,71 & 14,95 & 0,29 & 26,95 \\
\hline 22 & Natica zonalis & - & - & 0,04 & 3,07 & - & - & - & - \\
\hline 23 & Otopleura mitralis & 0,04 & 8,59 & - & - & - & - & - & - \\
\hline 24 & Strombus erythrinus & 0,04 & 8,59 & 0,04 & 3,07 & - & - & - & - \\
\hline 25 & Strombus sp.1 & 0,04 & 8,59 & 0,04 & 3,07 & - & - & - & - \\
\hline 26 & Trochus muculatus & 0,12 & 14,65 & 0,04 & 3,07 & - & - & 0,16 & 11,52 \\
\hline
\end{tabular}




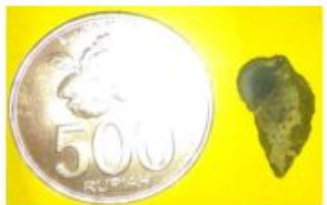

a

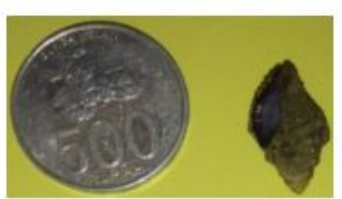

b

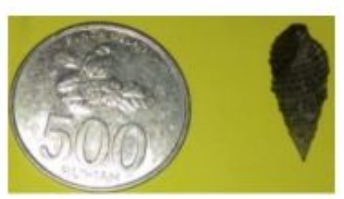

c

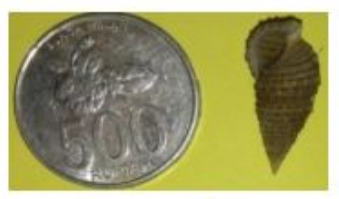

d

Gambar 3. Spesies yang banyak di temukan di Pesisir Dusun Karang Utara Pulau Lemukutan Kabupaten Bengkayang (a) Clypeomorus Moniliferus; (b) Cronia margariticola, Rhinoclavis articula; (c) dan Rhinoclavis bituberculata (d)

yang tersebar di body whorl. Sedangkan pada bagian bibir cangkang di area luar lebih tebal dibandingkan area dalam cangkang. Kusnadi et al. (2008) menyatakan bahwa jenis ini hidup di daerah pasang surut dan perairan dangkal.

Spesies lainnya yaitu Cronia margariticola juga terdistribusi pada daerah yang beriklim tropis seperti di wilayah Indo-Pasifik (Ishida, 2004). Menurut Ishida (2004) Cronia margariticola, sangat cocok hidup pada wilayah intertidal yang berbatu. Cronia margariticola memiliki bentuk cangkang yang mirip seperti belah ketupat selain itu cangkang Cronia margariticola memiliki Spire yang pendek dan tumpul (Gambar 3). Bentuk permukaan cangkang bertekstur tebal, padat dan kasar. Selain itu terdapat butir-butir keras pada whorl, namun pada permukaan tepi bibir bagian dalam terlihat licin mingkilap dan berwarna cokelat kemerahan.

Rhinoclavis articula merupakan salah satu spesies yang juga tersebar pada daerah tropis di wilayah Indo-Pasifik (Kusnadi et al., 2008). Rhinoclavis articula memiliki cangkang berwarna hitam pekat, dengan bentuk memanjang serta sisi cangkang membelok namun memiliki tekstur tebal dan ramping. Selain itu pada bagian luar cangkang terdapat butir-butir spiral yang kasar mengelilingi whorl namun tekstur cangkang pada bagian dalam terlihat licin, dengan warna yang sama seperti warna cangkang (Gambar 3).

Rhinoclavis bituberculata masih berkerabat dekat dengan Rhinoclavis articula sehingga dari bentuk cangkang dan serta habitatnya diduga sangat mirip. Rhinoclavis bituberculata memiliki cangkang memanjang dengan sisi membelok. Warna cangkangnya coklat muda serta terdapat nodul berderet spiral berwarna coklat tua mengelilingi whorl. Bentuk cangkang ramping dan tebal serta saluran analnya terlihat jelas (Gambar 3).

\subsection{Kelimpahan (K) dan Indek Nilai Penting (INP)}

Nilai Kelimpahan dan Indeks Nilai Penting (INP) secara keseluruhan pada masing-masing stasiun relatif berbeda. Perbedaan ini diduga karena lingkungan pada setiap stasiun yang bervariasi serta memiliki karakter lingkungan yang khas. Oleh sebab itu spesies yang mendominasi tiap stasiun juga relatif berbeda. Spesies yang mendominasi pada lokasi tertentu artinya lebih cocok pada kondisi lingkungan yang ditempatinya dari pada di lingkungan lain. Pada stasiun I total seluruh siput laut yang didapat berjumlah 15 spesies dengan kelimpahan tertinggi yaitu spesies Cronia margariticola dengan nilai kelimpahan 0,46 ind $/ \mathrm{m} 2$. Tingginya kelimpahan spesies Cronia margariticola diduga karena kondisi lingkungan dan waktu pengambilan sampel yang bertepatan dengan masa memijah, puncaknya terjadi pada bulan Mei-Juni, sedangkan pada bulan Juli terjadi proses ovi posisi (peletakan telur) Cronia margariticola (Ishida, 2004). INP tertinggi pada stasiun I adalah spesies Cronia margariticola dengan nilai 51,52\%. Menurut Yahya et al., (2016), Indeks Nilai Penting (INP) digunakan untuk menghitung dan menduga keseluruhan dari peranan jenis siput laut di dalam suatu komunitas. Semakin tinggi nilai INP suatu jenis relatif terhadap jenis lainnya, maka semakin tinggi peranan jenis pada komunitas tersebut (Yahya et al., 2016).

Pada stasiun II total seluruh siput laut yang didapat berjumlah 18 spesies dengan kelimpahan tertinggi adalah spesies Rhinoclavis articula dengan nilai kelimpahan $16,47 \mathrm{ind} / \mathrm{m} 2$. Rhinoclavis biasanya hidup di daerah pasang surut pada perairan dangkal, serta bersembunyi di bawah permukaan substrat (Kusnadi et al., 2008). Tingginya kelimpahan spesies Rhinoclavis articula, diduga karena lingkungan dengan subtrat 
Tabel 4. Indeks Keanekaragaman (H'), Kemerataan (E) dan Dominansi (C) pada setiap stasiun

\begin{tabular}{cccc}
\hline \multirow{2}{*}{ Stasiun } & \multicolumn{3}{c}{ Nilai Indeks } \\
\cline { 2 - 4 } & $H^{\prime}$ & $E$ & $C$ \\
\hline I & 1,88 & 0,70 & 0,28 \\
II & 2,02 & 0,70 & 0,16 \\
III & 0,66 & 0,24 & 0,70 \\
IV & 1,91 & 0,83 & 0,21 \\
\hline
\end{tabular}

pasir berlumpur paling cocok untuk menunjang kehidupannya, jika dibandingkan dengan lokasi lain dengan substrat berbeda. Nilai INP tertinggi pada stasiun II adalah spesies Rhinoclavis articula dengan nilai $26,70 \%$. Tingginya INP pada spesies Rhinoclavis articula disebabkan oleh tingginya jumlah spesies ini pada semua plot di stasiun II. Keberadaan spesies Rhinoclavis articula yang tinggi berkaitan dengan tersedianya sumber makan yang yang diperlukan oleh spesies ini. Sumber makanan spesies Rhinoclavis articula berupa partikel-partikel material organik di sekitar mangrove yang terkandung dalam sedimen berupa detritus maupun organisme yang lebih kecil untuk diserap sebagai nutrisi bagi tubuhnya (Skilleter, 1991).

Pada stasiun III total seluruh siput laut yang didapat berjumlah 15 spesies. Kelimpahan tertiggi adalah spesies Clypeomorus moniliferus dengan nilai kelimpahan 21,75 ind $/ \mathrm{m} 2$. Clypeomorus moniliferus ditemukan pada semua plot di stasiun III dengan total jumlah 1.631 spesies. Tingginya kelimpahan spesies Clypeomorus moniliferus diduga karena kesesuaian kondisi lingkungan pada kawasan ini yang memiliki substrat pasir berbatu. INP tertinggi pada stasiun III yaitu spesies Clypeomorus moniliferus dengan nilai $88,04 \%$. Spesies Clypeomorus moniliferus memiliki INP yang tinggi dibandingkan spesies lainnya pada stasiun III. Menurut Fosberg et al., (1961), spesies Clypeomorus moniliferus membentuk kelompok besar pada saat surut, bergerak perlahan untuk menjaga kelembaban dan ketahanan agar tetap berada di air yang minim. Diduga tingginya nilai INP karena penyebaran Spesies Clypeomorus moniliferus yang merata dan jumlahnya yang tetap stabil meskipun kondisi perairan dalam keadaan surut di setiap plot.

Pada stasiun IV total seluruh siput laut yang didapat berjumlah 11 spesies dengan kelimpahan tertiggi di stasiun IV adalah spesies Cronia margariticola dengan nilai
Kelimpahan 0,57 ind $/ \mathrm{m} 2$. INP tertinggi pada stasiun IV adalah spesies Cronia margariticola dengan nilai 38,37\%. Tingginya INP yang diperoleh spesies Cronia margariticola disebabkan berbagai faktor diduga salah satunya kondisi lingkungan yang sesuai dan ketersediaan makanan. Habitat spesies Cronia margariticola pada stasiun IV didominasi oleh substrat berbatu dan terdapat tumbuhan seperti alga sebagai salah satu sumber nutrisi bagi spesies ini.

\subsection{Indeks Keanekaragaman $\left(\mathrm{H}^{\prime}\right)$, Kemerataan (E) dan Dominansi (C) Siput Laut}

Kondisi suatu lingkungan dapat dikatakan baik apabila menunjukkan nilai indeks keanekaragaman $\left(\mathrm{H}^{\prime}\right)$ dan indeks kemerataan yang tinggi serta indeks dominansi yang rendah, demikian pula sebaliknya (Cappenberg et al., 2006). Siput laut di stasiun II, menunjukan kondisi ekosistem yang paling baik jika dibandingkan dengan 3 stasiun lainnya karena memiliki nilai $\mathrm{H}^{\prime}$ dan E tingggi serta nilai $C$ yang relative terendah (Tabel 4). Jumlah spesies pada stasiun II lebih banyak dari stasiun lain karena kondisi lingkungan pada stasiun II tergolong stabil dan cocok bagi pertumbuhan dan kehidupan siput laut. Sedangkan pada stasiun III dari hasil indeks yang didapat dinilai kurang baik karena memiliki nilai $\mathrm{H}^{\prime}$ dan $\mathrm{E}$ yang relatif rendah namun memiliki nilai $\mathrm{C}$ yang lebih tinggi dibandingkan ke 3 stasiun lainnya (Tabel 4). Spesies yang terdapat di stassiun III dinilai tidak stabil karena hanya spesies tertentu yang mendominasi, diduga hanya spesies yang mendominasi inilah yang mampu bertahan hidup pada kondisi lingkungan pada perairan stasiun III.

\section{Kesimpulan}

Berdasarkan hasil penelitian, dapat disimpulkan bahwa:

1. Siput laut yang didapat di Pesisir Dusun Utara Teluk Cina Pulau Lemukutan 
sebanyak 26 spesies terdiri dari 14 famili. Jenis siput laut yang paling banyak ditemukan terdapat 4 spesies yaitu Clypeomorus Moniliferus, Cronia margariticola Cronia margariticola dan Rhinoclavis articula.

2. Nilai indeks struktur komunitas siput laut yang terdapat di Pesisir Teluk Cina Pulau Lemukutan yaitu Indeks Keanekaragaman $\left(H^{\prime}\right)$ dengan nilai antara 0,66-2,02. Nilai indeks kemerataan (E) antara 0,24-0,83. Nilai indeks Dominansi (D) antara 0,16-0,70. Dari ke 4 stasiun, stasiun II memiliki indeks keanekaragaman yang tinggi dan kemerataan yang tinggi serta memiliki nilai dominansi yang rendah.

3. Lingkungan yang paling cocok bagi siput laut terdapat di stasiun II, karena memiliki keanekaragaman dan kemerataan yang tinggi dan dekat dengan tumbuhan mangove yang secara tidak langsung memberikan asupan nutrisi yang cukup bagi siput laut.

\section{Daftar Pustaka}

Cappenberg, H.A.W., Aziz and I. Aswandy. 2006. Komunitas moluska di perairan Teluk Gilimanuk, Bali Barat. Osea. D. Limno. di Indo., 40:53- 64.

Fosberg, F.R.; Thorne, R.F. and Moulton. J.M., 1961. Heron Ialand, Capricorn Group, Australia, A. Rese. Bull., 82:1-16.

Ishida, S. 2004. Life History of The Muricid Gastropod, Cronia margariticola (Broderip,1833): Growth Mode Transition with Season and Sexual Maturity, Sakyo, Kyoto, Japan. B. Rese., 59:35-44.

Kusmana, C.; Setyobudiandi, I.; Hariadi S. dan A. Sembiring, 2015. Sampling dan Analisis Bioekologi Sumber Daya Hayati Pesisir Laut, IPB press, Bogor.

Kusnadi, A.; Hermawan, U.E., dan Triandiza, T., 2008, Moluska Padang Lamun Kepulauan Kei Kecil, LIPI Press, anggota Ikapi, Jakarta.

Merdekawati, D.; Nurhayati, T., and Jacoeb, A.M., 2017, Kandungan Proksimat dan Mineral dari Keong Mata Lembu (Turbo setosus Gmelin 1791), J.Mina. Sai., 3:47-53.

Sudiono, G., 2008, Analisis Pengelolaan Terumbu Karang Pada Kawasan Konservasi Laut Daerah (KKLD) Pulau Randayan Dan Sekitarnya Kabupaten Bengkayang Provinsi Kalimantan Barat, Universitas Diponegoro Semarang, Semarang, (Tesis).

Schaduw, J.N.W., 2018, Distribusi Dan Karakteristik Kualitas Perairan Ekosistem Mangrove Pulau Kecil Taman Nasional Bunaken, M. Geo. Indo., 32:40-49.

Sinaga, A., dan Riwayati, 1999, Ekologi Perairan, FMIPA IKIP Medan.
Skillter, G.A., 1991, Distribution Abundance and Size Structure of Cerithiid Gastropods In Sediments At One Tre Reef, Southern Great Barrier Reef, J. Of Exp. Mar. Biol. and Eco., 151:185-207.

Wijayanti, H., 2007, Kajian Kualitas Perairan Di Pantai Kota Bandar Lampung Berdasarkan Komunitas Hewan Makrobenthos, Universitas Diponegoro, Semarang, (Tesis).

Yahya; Muzahar, dan Irawan, H., 2016, Struktur Komunitas Gastropoda Di Perairan Kampung Baru Lagotabeli Kecamatan Teluk Sebong Kabupaten Bintan, FKIP UMRAH, 1-14. 